\title{
Kjentmann på siste etappe
}

\author{
Da Ronny Dalene som turnuslege uforvarende ble tildelt rollen som tilsynslege på et stort \\ sykehjem, ba han sykepleierne sette opp en liste over de pasientene som trolig hadde kortest \\ tid igjen å leve. Deretter innkalte han de pårørende til samtaler. Han sier selv at han var vett- \\ skremt, men sikker på at han gjorde noe som måtte gjøres.
}

- Jeg liker å ha en plan, sier han, og mener i denne sammenhengen en plan for døden.

- En plan synliggjør at noen har tenkt og snakket sammen om det som skal skje, og hvilke situasjoner som kan oppstå. Som fersk sykehjemslege slo det meg at ingen $i$ behandlingskjeden egentlig hadde tatt inn over seg det åpenbare $\mathrm{i}$ at pasienten snart skulle dø og at det måtte forberedes. Jeg kunne bli tilkalt til et dødsleie der de pårørende aldri var blitt spurt eller informert om noen av de beslutningene vi som leger vet at vi må ta. Og jeg opplevde for ofte døende pasienter på sykehjemmet som var blitt innlagt på sykehus av en ukjent legevaktslege i løpet av natten fordi tilstanden hadde forverret seg, og ingen kunne med forankring i journalen eller forutgående enighet med pårørende si at «nei, henne flytter vi ikke på nå, hun skal få være her til det er slutt».

\section{Gi meg de sykeste}

Samtalen vår finner sted på mitt kontor i Seljord en sen ettermiddag i februar med dårlig sikt og ditto føre. Det er en vanlig dag på jobben. Ronny Dalene er på vei hjem til Skien fra besøk hos en pasient i Haukelid i Vinje sammen med pasientens unge fastlege. Google maps mener at turen én vei bør ta i overkant av to og en halv time, «uten trafikk» som man sier i urbane strøk. I dette distriktet er det sjelden kø. Vær derimot.

Sykepleieren som for noen år siden fikk mandat fra Sykehuset Telemark til å engasjere Ronny Dalene, er motoren bak opprettelsen av det frittgående palliative teamet i fylket. Hun reiser alltid med ut. Prosjektet er enestående ved at teamet - bestående av Ronny Dalene og sykepleier Torunn Haugstøl - er finansiert gjennom et spleiselag mellom helseforetaket og 17 av Telemarks 18 kommuner. Det er også enestående og ifølge Torunn Haugstøl en viktig nøkkel til suksess at teamet har lege i heltidsstilling. Siden oppstarten i 2013 har de to dokumentert 604 hjemmebesøk og mer enn 200 tilsyn med pasienter i kommunale sykehjem. At de har fått til noe spesielt har også nådd hovedstadspressen.

- Vi har akkurat hatt Dagbladets helgemagasin med oss rundt på jobb, forteller Ronny Dalene. Han sier det stolt, men også litt brydd. Hvis det er noe Ronny Dalene

\section{«lngen kan ta meg for à være en som ikke har fått prøvd seg i det virke- lige livet, på godt og vondt»}

$i k k e$ fremstår som, er det «jålete» eller «selvhevdende». Å lage et portrett av ham betyr at man er villig til å snakke om det han brenner for.

- Har dere innført sånn «time samme dag» i Seljord? spør han plutselig. - Nei ...

- Godt å høre. Jeg jobbet jo 12 år som fastlege. Det er der jeg har min identitet. Jeg er veldig opptatt av at fastlegeordningen må bestå og utvikles og tilsvarende bekymret for at fastlegene skal forfalle til å bli ekspeditører av bestillinger. Det er jo en viktig del av førstelinjens jobb å prioritere de sykeste, de som trenger det mest, sier han.

- Du har jo på en måte gjort det enkelt for deg selv, slik sett da?

- Ja, jeg innrømmer det. Det var et valg. Kanskje kunne jeg blitt i allmennpraksis, men jeg strevde i tiltagende grad med å orke alt som jeg selv ikke syntes var viktig nok eller trengte min tid og mitt engasjement. Dessuten er jeg for snill og pliktoppfyllende. Det er mye mindre slitsomt å reise Telemark rundt til de sykeste syke enn det etter hvert var å sitte som fastlege for stort og smått.

Ronny Dalenes telefonnummer ligger trolig på de fleste fastlegers mobiltelefoner i Telemark, står i merknadsfeltet i journalen til de dårligste pasientene, henger på oppslagstavlen i ekspedisjonen på legekontorene, ligger på en lapp på nattbordet eller henger festet med magnet på kjøleskapet $i$ veldig mange hjem. Å ringe til Ronny er enkelt, samtalene er oftest korte og konkrete. Han er lege med kunnskap om hva som virker, og hva som er mulig innenfor de gitte rammene, ikke sjelesørger eller prest.

- Jeg har sett det som min oppgave å omsette de fine og ofte generelle vendingene man er veldig enige om på konferanser og kongresser til praktisk virkelighet ute, sammen med dem det gjelder, pasientene og de pårørende og de nære hjelperne. Da må man være konkret og tydelig.

\section{Å ta på det vonde}

«Konkret» er et stikkord her. Ronny Dalene har litt forenklet sagt med seg to verktøy når han reiser rundt til pasienter og pårørende som vet at døden venter rundt neste sving. Han har oppskriften på behandling av de symptomene alle pasienter jeg selv har møtt ute i praksis, er mest redde for i den siste fasen: smerter, kvalme, ikke å få puste, angst og uro. Fire medikamenter er nesten alltid tilstrekkelig. Hjelperne ute får en detaljert oversikt over indikasjon, dosering, administrasjonsmåte, komplikasjoner og fortløpende dokumentasjon av effekt og bivirkninger. Minst like viktig er det at han har utviklet det man må kunne kalle en opp- 


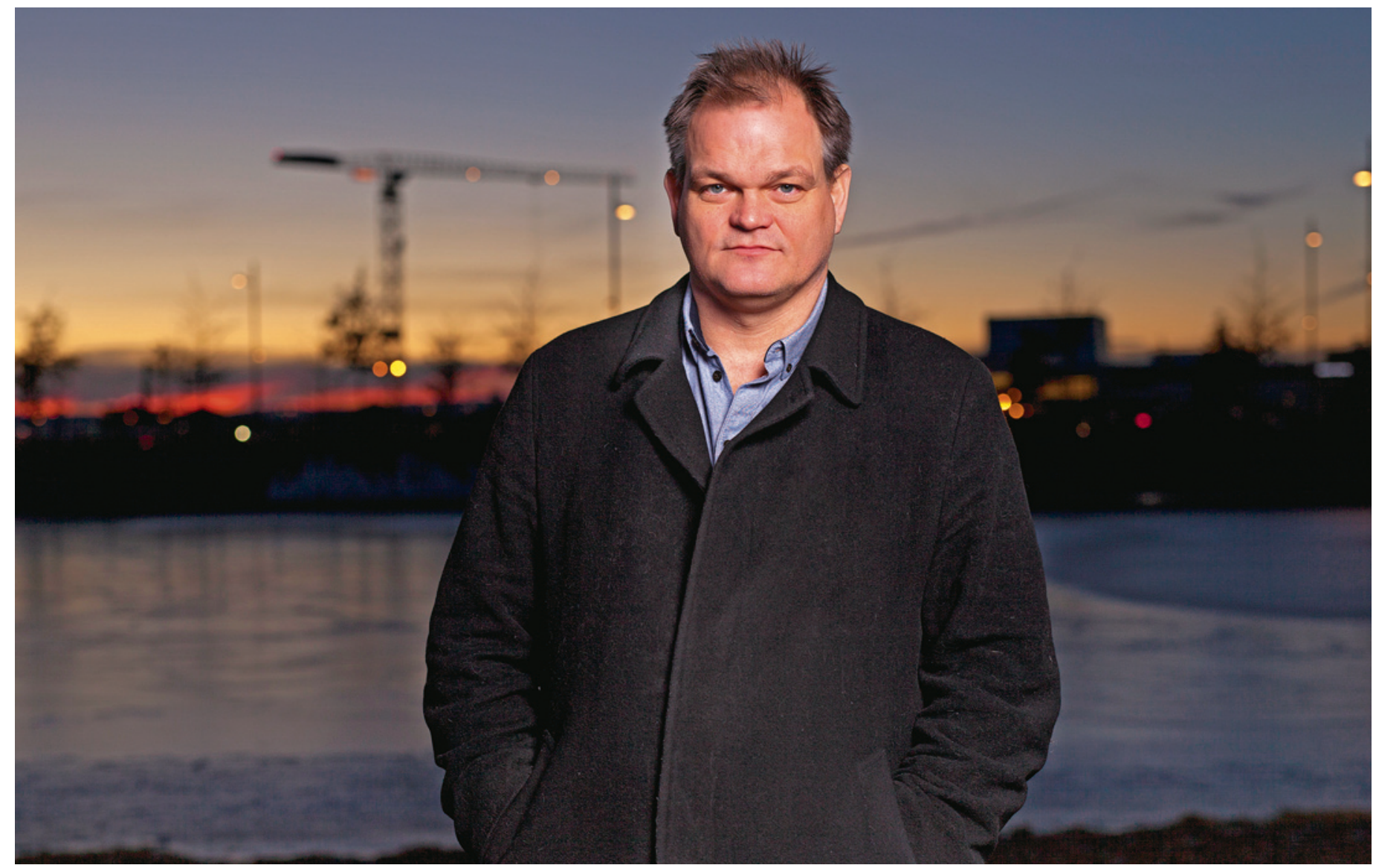

Foto: Niklas Lello

\section{Ronny Dalene}

født 1970 i Porsgrunn

- Cand.med. Universitetet i Bergen 1997

- Assistentlege Onkologisk avdeling, Haukeland sykehus 1997-1999

- Fastlege Porsgrunn kommune 2002-2013

- Tilsynslege Frednes lindrende enhet 2007-2012

- Nordic Specialist Course in Palliative Medicine 2011-2013

- Overlege palliativ enhet, Sykehuset Telemark 2013-

- Underviser på sykepleieutdanningen ved Høgskolen i Telemark 2003 -

- Aktiv i utarbeidelsen av nettbasert undervisningsopplegg innen kompetanseområdet palliativ medisin skrift for samtale med de pårørende om det de erfaringsmessig er mest redde for og usikre på. «Pårørendesamtalen» slik interesserte lesere kan finne den i kursformat tilgjengelig for alle - på Legeforeningens nettside, er Ronny Dalenes oppfinnelse. Han har for øvrig ikke tall på alle de kursene han etter hvert har holdt for leger og annet helsepersonell.

Her skal det gis rom for en personlig parentes. I 2009 var jeg medansvarlig for et kurs i regi av Norsk forening for allmennmedisin om døden. Vi var opptatt av å belyse både de etiske, religiøse og praktiske utfordringene rundt det å dø. Etter at deltagerne sammen med prest og etiker hadde drøftet meningen med livet og dødens imperativ og de store spørsmål, kom Ronny Dalene som vi den gang bare kjente som en kollega som drev med palliasjon i sykehjem. Han gikk rett på. «Her er medisinene, og slik ser malen for pårørendesamtalen ut. Når barna spør hvorfor mor ikke skal få mat og vann, skal du si følgende: ...».

Det hører til de mer morbide minnene fra kurset at det ble holdt $i$ et hotell rett ved Dyreparken i Kristiansand. Kurslokalet hadde store vinduer ut mot Kaptein Sabeltanns rike, og hver halvtime seilte sjørøver- skuta med skjeletter langs rekka og hodeskalleflagget til topps forbi. Død og dødsangst er også en sikker kommersiell suksess.

Kurset ble også oppsummert som en suksess, særlig Ronny Dalenes direkte tale. - En av mine unge kolleger har fortalt at hun satt med din mal for pårørendesamtalen under bordet mens hun snakket med ektefellen til en døende pasient. Og at den virket!

- Jeg er først og fremst kliniker, men opptatt av systemer og logistikk. Det jeg driver med, skal kunne læres av andre og integreres i førstelinjen. Hvis vi begynner å spesialisere døden, hva da?

Han forteller at ikke alle har vært like begeistret for graden av konkretisering og standardisering i det han formidler.

- Hva med tilbakemeldingene fra pasienter og de kollegene ute som du samarbeider med?

- Jeg må med hånden på hjertet si at de har vært entydig positive. Det er lett for meg å forstå at unge, nye fastleger kan være redde for hele situasjonen rundt en døende pasient. Du skal både signalisere faglig trygghet og autoritet, og samtidig være lydhør for ønsker og krav fra de pårørende. Jeg mener at vår metode og de verktøyene vi 
har utviklet, har vist seg nyttige. Det var også en enorm lettelse da Helsedirektoratets veileder om livsforlengende behandling kom i 2013. Da fikk vi en helt annen faglig ryggdekning for det vi hadde drevet med etter beste evne, basert på erfaring og den relativt sparsomme forskningen som forelå.

\section{Ronny fra Bamble}

Han er glad for navnet sitt. Sykepleier Torunn Haugstøl ler bekreftende når jeg spør henne: «Det er fantastisk, rett og slett en gave», sier hun. Ronny Dalene har ingen leger i familien og har - etter en i og for seg grei barndom - ikke hatt noe sikkerhetsnett, snarere måttet ordne opp og ta ansvar og håndtere det meste selv. Han dveler lite ved det, sier bare kort at han har opplevd «mange tap».

- Det er veldig greit å være Ronny fra Herre $\mathrm{i}$ Bamble når jeg er hjemme hos pasienter. Ingen kan ta meg for å være en som ikke har fått prøvd seg i det virkelige livet, på godt og vondt. Jeg har aldri fått med meg den tause kunnskapen som nedarves $i$ enkelte familier og miljøer om at leger nærmest a priori er litt klokere og litt finere enn folk flest. Mens jeg studerte i Bergen prøvde jeg kanskje en stund å legge meg til mer sofistikerte interesser og meninger som jeg trodde hørte med til statusen, men etter at jeg flyttet hjem igjen er det typiske guttegreier som gjelder på fritiden. Fotball og ølbrygging og fisking. Og utstyr og blader og sånt. - Blader? Fiskeblader?

- Ja, ja. Masse fine greier.

Ronny Dalene er en begavet pedagog og har en måte å ferdes på som får mennesker til å senke skuldrene. Det er ikke lett å få til en dialog, heller ikke et godt læringsmiljø, om vanskelige ting hvis man er ubekvem og redd.

- Vet du hva du gjør? Er det et talent?

- Ja og nei. Jeg har jo vært veldig opptatt av at det jeg gjør i møte med døende og pårørende kan læres av alle. Når det er sagt, har jeg nok en egen evne til å lese kjapt hvem jeg har foran meg, intuitivt forstå relasjoner, en sosial teft. Faren min var arkitekt. Det er antagelig fra ham jeg har arvet et blikk for sammenhenger og en løsningsorientert, praktisk tilnærming til det jeg ser.

$\AA$ vite hva som virker, er en forutsetning for å kunne lære det videre. Ronny Dalene kan redegjøre i stor detalj om hvilke virkemidler han bruker, og hva som fungerer når og hvordan og hvorfor. Han trekker selv frem trenermetaforen, å gjøre de andre gode.

- Det er trist å se fotballspillere i verdensklasse som ikke klarer å formidle hvorfor de lykkes, og dermed mislykkes som trenere.

\section{Hva tenker dere om det?}

Det er pårørendesamtalen som er Ronny Dalenes viktigste bidrag til oss som følger pasientene helt til døren. Erfaringsmessig er legene reddere for de pårørende enn for pasienten. Man kan tross alt sin medisin, men å snakke med opprørte, triste, redde mennesker som ofte holder legen ansvarlig langt ut over det rimelige eller forutsigbare, er akkurat så skummelt og vanskelig som dette leses. På sykehus er man tross alt mange rundt en sykeseng, ute i de små kommunene ofte bare én lege og hjemme-

\section{«På sykehuset blir alle like. Hjemme er alle forskjellige»}

sykepleierne. Ronny Dalene er opptatt av at pårørendesamtalen både fungerer som en anledning for de pårørende til å få svar på ting de lurer på, men også er et verktøy for å gi legen mandat til å gi pasienten best mulig lindring.

- Det er legen som aktivt skal ta initiativ til samtalen med de pårørende om de selv ikke allerede har gjort det. Vi bør begjære den samtalen.

- Begjære?

- Ja. Det sto på en serviettpakke som jeg kjøpte med meg fra Nille - noe sånt som at «det viktigste i all kommunikasjon er å høre det som ikke blir sagt». Jeg ble kjempeprovosert. Akkurat den formuleringen ville jeg ha funnet på selv. Pårørendesamtalen kan gi oss en anledning til å få tak i det som ikke blir sagt.

- De som har sett malen din for samtalen, kan mene at du blir veldig styrende? At de pårørende kan føle seg overkjørt?

- Det er en del av legens jobb å utøve profesjonelt lederskap. I den palliative fasen må vi ta ansvar for å unngå kaos og skape ro, samtidig som vi må passe på ikke å blokkere dialogen. Vi lærte jo i studiet at det er veldig viktig med åpne spørsmål. Ja, i en innledende fase og for å sikre at man får med seg nok informasjon til å forstå hvem og hva man har med å gjøre, er nok det riktig. Men når vi skal begynne å snakke om selve prosessen, de vanskelige faglige beslutningene rundt ernæring, væske og medisinering i den siste fasen, er det min erfaring at det fungerer best når jeg sier det jeg har å si, og deretter sikrer at de pårørende får komme med sitt. For eksempel la jeg merke til at det er stor forskjell på å si: «Har dere forstått hva jeg sier?» eller «Er dere enige i det?» og slik jeg formulerer meg: «Hva tenker dere om det?». De to første fungerer mer som kontrollspørsmål enn som en invitasjon. Når man spør pårørende om hva de tenker, opplever man jo at de er like kloke og reflekterte som legen. Det blir en mer likeverdig relasjon der rollene er ulike, men i øyehøyde.

\section{Se meg}

Ronny Dalene spiller fotball flere kvelder i uken, dessuten løper han. Det er nok bra, for hjemmebesøk i Telemark er ensbetydende med mange måltider tilberedt med den omsorgen et dødsleie tilsier. Om ikke pasienten lenger kan ta til seg elgkarbonader, lefse og kjøttsuppe, så skal sannelig legen spise!

- I begynnelser feilberegnet jeg litt, for eksempel når vi skulle på tre hjemmebesøk etter hverandre. Jeg kan jo ikke si nei takk heller.

- Er det et mål at alle skal dø hjemme?

- Nei! Noen hjem kan man ikke dø i. Og noen prosesser er slik at ikke alle hensyn kan ivaretas godt nok hjemme. Jeg vet ikke nå om jeg for eksempel vil velge å $\mathrm{d} \varnothing$ hjemme, hva som vil bli viktigst for meg. Vi må for all del ikke skape ideer om et slags A- og B-lag der det blir et nederlag å dø i sykehjem eller på sykehus. Poenget må være at folk skal få være hjemme så lenge de kan og vil.

Telemark kalles ofte et «Norge i miniatyr»: kyst og fjell, landets mest konsentrerte moderne tungindustri i det tett befolkede Grenland i sørøst, og tradisjonsrik bygdekultur med vekt på nedarvede skikker i nordvest. Ronny Dalene kan saktens ha bruk for sin relasjonelle fingerspitzgefühl.

- Det skjer noe når man kommer hjem til pasienter som er veldig syke. På sykehuset blir alle like. Hjemme hos seg selv er alle forskjellige. «Se meg som den jeg var før jeg ble syk» blir et viktig budskap til hjelperen i en fase da pasienten på mange måter mister seg selv.

- Min egen opplevelse er at du blir tatt imot som en velkommen gjest når vi er ute sammen hos pasientene.

- Og jeg takker alltid for at jeg får komme.

Elisabeth Swensen

elswense@online.no 